\title{
- Sistema Político dos EUA: Implicações para suas Políticas Externa e de Defesa*
}

Antonio Jorge Ramalho da Rocha**

“[...] but suppose we were (as we might be) an influence, an idea, a thing intangible, invulnerable, without front or back, drifting about like a gas? Armies were like plants, immobile, firm-rooted, nourished through long stems to the head. We might be a vapour, blowing where we listed. Our kingdoms lay in each man's mind; and as we wanted nothing material to live on, so we might offer nothing material to the killing."1

\section{Introdução}

Este texto visa discutir características do sistema político norte-americano e valores enraizados na sociedade dos EUA que, ao longo do tempo, produziram fortes implicações para a atuação externa deste país. Centrada nos interesses de longo prazo dos Estados Unidos da América, a discussão ressalta o modo como este país, ao

\footnotetext{
*Artigo recebido em dezembro de 2005 e aprovado para publicação em janeiro de 2006.

**Doutor em Sociologia pela Universidade de São Paulo (USP) e professor adjunto do Departamento de Relações Internacionais da Universidade de Brasília (UnB).
}

CONTEXTO INTERNACIONAL Rio de Janeiro, vol. 28, nº 1, janeiro/junho 2006, pp. 53-100. 
participar ativamente da construção da ordem e dos principais processos políticos internacionais contemporâneos, projetou seus interesses na arena internacional.

Ao difundirem no contexto internacional valores tipicamente característicos da sociedade norte-americana, os EUA contribuíram - e contribuem - para redefinir os termos que pautam a interação de agentes no âmbito internacional. Reconfiguram-se, por assim dizer, "as regras do jogo". O ambiente global transformou-se em um espaço mais favorável à concretização de práticas e relações sociais outrora confinadas a territórios e populações historicamente marcados pela ampla aceitação de valores democráticos e liberais ${ }^{2}$. Ao cabo, normas e valores funcionam como instrumentos de projeção de influência no ambiente internacional.

O texto divide-se em duas partes, além de breves introdução e conclusão. A primeira parte apresenta o arcabouço conceitual a ser utilizado para analisar a influência de normas e valores sobre o comportamento de agentes na esfera internacional e discute os processos por meio dos quais os EUA nela inseririam normas e valores norte-americanos. Refere-se, ainda, a marcantes transformações nas relações internacionais contemporâneas, que resultaram, ao menos em parte, da consolidação de padrões de relacionamento definidos no contexto desse arcabouço normativo. A segunda parte examina valores específicos da sociedade norte-americana e sua influência na conformação de identidades e de interesses permanentes dos EUA, tanto no que diz respeito à realização de suas potencialidades quanto no que se refere à relação do país com outros Estados e sociedades. Ao longo do texto, analisa-se, ainda, o modo como o governo norte-americano buscou projetar valores no contexto internacional, visando construir um ambiente mais favorável à concretização de seus objetivos. 
O Sistema Político dos EUA: Implicações para

suas Políticas Externa e de Defesa

\section{Agentes e Estruturas no Contexto Internacional Contemporâneo}

\section{Discursos sobre agentes e estruturas na interdependência}

Se existe um consenso entre os analistas das relações internacionais contemporâneas, é o entendimento de que a interdependência de Estados e sociedades no contexto internacional muito se ampliou ao longo dos últimos séculos. A dimensão e a profundidade deste processo, seus agentes principais, as forças que o promovem, suas implicações, tudo tem sido debatido à exaustão, havendo mesmo ensejado o surgimento de um novo campo de estudo nas ciências humanas, o das Relações Internacionais.

Os termos por meio dos quais os analistas tentam conferir sentido a esse processo são muitos. Discursos normativos, declarações assertivas sobre como o mundo deve ser e sobre como os indivíduos devem se comportar, umas fundadas em convicções, outras em interesses, todas prenhes de intenções, explícitas ou não, de transformação da realidade. Assim, numerosos discursos ideológicos, religiosos ou apenas preconceituosos manifestam-se aprioristicamente favoráveis ou contrários a esse complexo processo, que vulgarmente - ou nem tanto - se denomina "globalização".

O texto de Huntington (1996) sobre o choque de civilizações relembrou os analistas da necessidade de se considerarem as influências deste tipo de discurso, por mais abstrato ou utópico, sobre a realidade propriamente dita. Ao fazê-lo, reinseriu no debate, talvez não da melhor maneira, a consciência de que nenhuma avaliação profunda de processos sociais, especialmente na frágil sociedade internacional, pode desconsiderar o modo como estruturas normativas e axiomáticas interferem na formação de preferências e na produção de condições de entendimento e espaços de negociação entre agentes sociais. 
Dessa maneira, contribuiu para que se revalorizassem explicações sociológicas das relações internacionais, abrindo espaço para aproximações construtivistas ${ }^{3}$.

De outro lado, há discursos científicos que também buscam interpretar, de forma rigorosa, esse processo de interdependência, suas origens e suas implicações. Há autores que privilegiam explicações da realidade baseadas em causas econômicas; outros que enxergam na raiz do incremento da interdependência motivações políticas. Conforme as presunções que se estabeleçam, obviamente, diferentes sistemas conceituais serão utilizados para contar a história da intensificação das relações internacionais nos últimos séculos. Parece haver consenso, contudo, com relação à natureza multidimensional desse processo, de modo que convém utilizar mais de um sistema conceitual, de forma combinada, para conferir sentido a essa realidade tão difícil de se interpretar.

Uma maneira concatenada de empreender esse esforço consiste em organizar a discussão em termos da interação de agentes e estruturas. Desde que se aceite a simultânea existência de diferentes estruturas no ambiente internacional ${ }^{4}$, e sua inter-relação, é possível analisar a extensão e a profundidade da interdependência que se observa nas interações de distintos agentes não apenas uns com os outros, mas deles, coletivamente, com estruturas que nem sempre respeitam as fronteiras nacionais.

A discussão sobre agentes e estruturas não é, contudo, nova ou simples $^{5}$. Dela participam autores que concentram sua atenção nas interações dos agentes, ressaltando que eles não agem no vácuo, mas intermediados por um conjunto de estruturas que servem à projeção de poder em diferentes dimensões, da militar à tecnológica, da financeira à comercial ${ }^{6}$. De modo mais sutil, ainda com ênfase na mútua interação de agentes, Nye, por exemplo, trabalha com a perspectiva de "poder brando", visto como uma forma de projeção de valores desti- 
nada a permitir que o agente exerça influência pela via da atração, mais do que pela coerção ${ }^{7}$. Desse ângulo, os governos são vistos como agentes unitários e racionais, que buscam avançar seus interesses por meio da formação de agenda e estabelecimento de estruturas conducentes a beneficiar aqueles capazes de influenciar a definição das posições de política externa do Estado (presumivelmente seus nacionais), em detrimento de outros agentes.

Participam também autores que se preocupam mais com a relação entre agentes e estruturas, seja defendendo pontos de vista que afirmam a possibilidade da governabilidade em diferentes áreas das relações internacionais sem a necessária constituição formal de um governo que exerça autoridade ${ }^{8}$, seja simplesmente identificando o modo como estruturas de idéias condicionam agendas, preferências, interesses e, em alguns casos, a própria identidade dos agentes (Wendt, 1987; 1999; Onuf, 1988).

As diferentes ênfases conferidas pelos analistas às dimensões da interdependência que se aprofunda entre governos e sociedades não mudam, contudo, a complexidade do processo em si. Ao cabo, observa-se, de início, aprofundar-se a integração de mercados, das estruturas produtivas e financeiras da economia global, engendrando o estabelecimento de regras comuns para disciplinar o intercâmbio e os fluxos de bens e serviços, de ativos financeiros, de informações e de pessoas; observa-se também, ato contínuo, o aumento do grau de interdependência na área de segurança, tradicionalmente reservada aos governos 9 .

No plano da economia política internacional, concretiza-se, em alguma medida, a previsão de Montesquieu: à proporção que se desenvolve o comércio internacional, amplia-se o custo político de realizar guerras, visto que não interessa a governo algum destruir a capacidade produtiva de seu mercado consumidor ou de economias de outros países que, como fornecedoras, se relacionem diretamente com seus 
nacionais. A interpenetração de mercados cria, assim, constrangimentos estruturais que tendem a fazer convergir os interesses dos governos no plano interno e no plano internacional, reduzindo a probabilidade de ocorrência de conflitos armados ${ }^{10}$.

Ao fortalecer esse processo, emerge um conjunto de regimes internacionais que promovem a convergência de expectativas dos agentes em áreas específicas das relações internacionais. A homogeneização de comportamentos contribui para consolidar estruturas produtivas e comerciais, que se organizam em redes, movidas pela lógica de redução de custos e de maximização de benefícios na alocação de recursos escassos, o que obviamente desconsidera as fronteiras políticas e impõe aos governos constrangimentos para aderir à normativa internacional (Krasner, 1983) ${ }^{11}$.

Esse fenômeno não deixa de produzir implicações políticas e sociais. Com efeito, de um lado, o livre fluxo de informações, bens e serviços permite a utilização de agentes políticos e sociais domésticos por outros governos, por meio ora de grupos de pressão, ora de redes produtivas e da possível manipulação da opinião pública. De outro lado, à medida que os governos permitem que se amplie a participação de outros agentes da sociedade em processos decisórios relevantes - e essa foi a tônica dos últimos dois séculos, especialmente pela via da democratização nas relações políticas -, reduz-se a sua capacidade de decidir, autonomamente, sobre a realização de guerras.

O incremento da participação da sociedade nas decisões de política externa de seus governos constitui fenômeno relativamente recente. Embora a Guerra do Vietnã seja por muitos considerada marco importante nesse processo, outros eventos também merecem destaque. De fato, já no início da Primeira Guerra Mundial, esse fenômeno recebeu a entusiástica adesão das populações européias à guerra "que poria fim a todas as guerras"; como é sabido, contudo, os desdobramentos da guerra e sua longa duração levaram as populações a desa- 
O Sistema Político dos EUA: Implicações para suas Políticas Externa e de Defesa

provar o conflito. A prevalecente leitura de que a Primeira Guerra resultou de acordos secretos mutuamente contraditórios, expressa na idéia de que a guerra seria muito importante para ser deixada a cargo apenas dos generais, e a decisão, ao seu final, de se criar uma instituição internacional destinada a proibir a guerra entre Estados e a tornar mais transparentes seus compromissos internacionais contribuíram para a difusão da idéia de que as sociedades não podiam permitir que os conflitos internacionais evoluíssem ao ponto de não-retorno.

Em outras palavras, tratava-se de evitar que se estabelecesse uma condição em que já não fosse possível resolver controvérsias por meios pacíficos. Mas como fazê-lo? Como assegurar que os governos não voltassem a realizar pactos que pudessem levar a um novo conflito de grandes proporções? A resposta parecia impor-se lógica, senão naturalmente: se o uso disciplinado da razão servira a produzir estimulantes resultados em tantas dimensões da vida humana, por que não o faria também no campo da política internacional? Afinal, em diversos países, a construção de instituições adequadas servira a organizar formas menos violentas de intermediação de interesses e de solução de conflitos.

Nessas condições, a proposta de criação da Liga das Nações, embora carregada de idealismo, veio a enraizar-se não apenas em uma cultura fundacionista, mas também na clara convicção de que instituições adequadas poderiam servir para construir ambientes políticos mais equilibrados.

\section{Os Estados Unidos no processo de organização das relações internacionais}

A proposta de criação da Liga das Nações, pelo presidente Wilson, em meio a um conjunto de pontos genuinamente realistas, não foi coincidência: sua inspiração, fortemente marcada pela experiência nor- 
te-americana, veio ao encontro de um processo de ampliação da presença dos EUA no cenário internacional - coroada, não é demais lembrar, pelo fim da Primeira Guerra Mundial. A idéia do constitucionalismo, herdada de uma tradição do Direito Natural que Onuf (1998) denominou "republicanismo atlântico", possibilitou que se conferisse personalidade jurídica a entes abstratos, que, uma vez reconhecidos pelos demais como "pessoa", habilitavam-se a assumir compromissos em nome de seus súditos ${ }^{12}$. A assunção de compromissos, por sua vez, permitiu dar início a relações sociais, políticas e econômicas que, afinal, serviram para consolidar a soberania dos Estados, ao conferir substância a suas interações.

Na Europa, esse artifício legal contribuiu para a consolidação do sistema westphaliano de Estados, amparado tanto nos interesses políticos dos soberanos de então - que tinham como pano de fundo a regulação de mercados em escalas compatíveis com as condições econômicas da época -, quanto em fundamentos conceituais trabalhados, no plano da filosofia política, principalmente pelos contratualistas. No nascente âmbito internacional, refletiram sobre o assunto pensadores como Bodin, Vattel, Grotius e Kant. Obviamente, o benefício do mútuo reconhecimento da soberania nacional figurava fortemente na maior liberdade dos soberanos para definir as regras do jogo para os súditos e territórios reconhecidos como seus. Situações históricas específicas condicionaram a aceitação dos princípios de soberania e territorialidade em graus e ritmos distintos, como ilustra a própria concessão de nacionalidade aos cidadãos baseada ora no local de nascimento (jus soli), ora em laços sangüíneos (jus sanguinis) ${ }^{13}$.

Gradualmente, por meio de conceitos como o de territorialidade e soberania, cindiram-se processos internos e internacionais, legitimando em textos legais a relação de cada governo com seus cidadãos e a de governos soberanos entre si. A Declaração de Independência dos Estados Unidos da América ${ }^{14}$ desempenhou, nesse contexto, papel relevante. Por seu intermédio, em nome de valores abstratos de direi- 


\section{O Sistema Político dos EUA: Implicações para suas Políticas Externa e de Defesa}

to à vida, à liberdade e à busca da felicidade, além da prerrogativa de combater a opressão, e na condição de representante do povo das treze colônias, um grupo de indivíduos desafiou a autoridade constituída, recorrendo a sofisticada argumentação para instituir um governo que deveria, a um só tempo, derivar sua legitimidade do consentimento da população e evitar usurpações de direitos - tipicamente empreendidas por governos tiranos.

Embora a idéia de uma soberania parlamentar não fosse nova, como ressalta Teschke (2002), jamais se observara, historicamente, a estrita submissão do próprio Parlamento ao povo. Assim, pela primeira vez essas idéias ganharam concretude em uma situação real. Mais que isso, tratava-se de um contexto percebido como particularmente rico em condições para que se enraizassem instituições liberais, dado que os oceanos protegiam indivíduos dispostos a viver "o sonho americano". Nessas condições, fortaleceu-se a soberania popular e o princípio da representação por meio da explícita constituição de um governo destinado a cumprir mandatos em benefício dos indivíduos $^{15}$. Principalmente, em essência, a proposta visava assegurar e promover liberdades individuais amparadas em instituições tipicamente liberais. A Revolução Francesa, com sua ênfase na promoção da igualdade, muito contrastou com a independência dos EUA, acentuando-lhe as especificidades.

Na opinião dos Pais Fundadores, a constituição de uma entidade soberana não podia prescindir de documentos que lhe registrassem a origem e que lhe assegurassem condições de perpetuar os valores em nome dos quais se inaugurara, com sangue, sonhos e saberes, nova experiência histórica. A novidade estava também, em alguma medida, na ausência de origem divina atribuída ao Estado: fazia falta, então, outro mito fundador, espaço rapidamente ocupado pela idéia da convergência de vontades dos cidadãos, logo simbolizada por uma espécie de contrato social. Fazia falta, com efeito, um registro desse 
pacto entre os cidadãos, relação que se buscou justificar pela crescente sofisticação do argumento contratualista: com Hobbes (1996), defendeu-se a necessidade de um artifício que constituísse a ordem e preservasse a vida; Locke (1952) deixou claro que não bastava uma ordem qualquer, uma vez que os indivíduos careciam - presumia-se que haveriam sempre de carecer - de um ambiente no qual sua vida e sua propriedade, fruto de seu trabalho sobre a natureza, estivessem protegidas; Rousseau (1968), por fim, inseriu a noção de dinâmica social e, na linha do argumento de Maquiavel (1985) nos Discursos sobre a Primeira Década de Tito Lívio, sugeriu formas de aperfeiçoamento das instituições.

Nesse contexto, a Declaração de Independência dos EUA não deixou margem a questionamentos em relação à soberania dos indivíduos e à necessidade de se constituir um arcabouço legal que os protegesse das prováveis tentativas de tiranização dos governantes. Os artigos federalistas, em seguida, veicularam as discussões conceituais sobre as melhores instituições políticas, condensando experiências históricas e reflexões teóricas com vistas a produzir o arcabouço normativo mais apto a promover a liberdade individual. A Constituição, por fim, perenizou, em seu preâmbulo, a vontade atribuída ao povo: "formar uma União mais perfeita, estabelecer Justiça, assegurar a tranquiilidade doméstica, prover a defesa coletiva, promover o bem-estar geral e resguardar as bênçãos da Liberdade [Blessings of Liberty] para nós mesmos e para a posteridade" $"$.

Em outras palavras, a própria fundação dos EUA constituiu uma redefinição dos termos por meio dos quais os indivíduos se relacionavam com seus governos. Ao fazê-lo, inseriu entre os valores tidos como integradores da sociedade norte-americana a idéia de "destino manifesto" da nação ${ }^{17}$. Ademais, conferiu à opinião pública papel relevante na definição de prioridades políticas no âmbito interno e na esfera internacional. 
O Sistema Político dos EUA: Implicações para suas Políticas Externa e de Defesa

Essa transformação dos termos, que levou a discutir, publicamente, a relação entre súditos e soberanos, teve lugar em circunstâncias marcadas por peculiares dinâmicas políticas internacionais e domésticas: no plano internacional, prevalecia a independência dos Estados e a progressiva constituição do que Bull denominou "sociedade anárquica"; no plano interno aos Estados, fortalecia-se, em várias sociedades, a idéia de que era necessário proteger o indivíduo da concentração de poder pelo governo, em virtude da tendência dos governos de tiranizar os cidadãos. Estabelecer estruturas institucionais e normativas eficazes afigurava-se, então, como instrumento adequado para levar a efeito essa proteção, ao se restringir a capacidade dos governos de utilizar a força (ou de ameaçar fazê-lo). Não por coincidência, a experiência norte-americana tornou-se símbolo desse processo: afinal, a Declaração de Independência precedeu em mais de uma década a Constituição norte-americana; esta, por sua vez, instituiu-se em meio a profundas desconfianças em relação à concentração de poder que se observaria em mãos de uma União que se criava com o objetivo precípuo de defender a sociedade de ameaças externas.

Se as origens da maior participação da opinião pública em processos decisórios internacionais podem ser localizadas na independência norte-americana e na Revolução Francesa, merece destaque a progressiva organização das relações internacionais que teve lugar ao longo do século XIX, evidenciada no surgimento de organizações internacionais e no uso de novas tecnologias de transportes e comunicações. Por sua vez, a aplicação pela Grã-Bretanha do conceito de guerra total, durante a Primeira Guerra Mundial, e suas implicações transformaram as relações internacionais contemporâneas.

De início, os desenvolvimentos tecnológicos e sua aplicação marcial - parte dos quais se testou na Guerra Civil norte-americana - diluíram as fronteiras entre o campo de batalha e a cadeia de suprimentos necessária para sustentar, com a contribuição de inovações logísticas, o esforço de guerra. Os conceitos de campo de batalha (front) e 
de retaguarda tiveram que ser revisitados e a capacidade econômica passou a ser considerada tão relevante quanto a capacidade militar propriamente dita, visto que esta não produziria todos os seus resultados sem o eficaz suporte daquela. Nessas condições, a população civil, outrora poupada pelos militares em nome de normas de combate ou, no mínimo, considerada alvo secundário, passou a ser extremamente relevante no esforço de guerra. Afinal, o corte de suprimento, de munição ou de alimentos passou a ser mais diretamente relacionado ao objetivo militar, pouco importando que os funcionários das indústrias fossem civis (menos ainda que fossem mulheres) incorporados à força de trabalho em razão da inevitável escassez de mão-de-obra causada pela guerra prolongada.

Como resultado, as populações mundo afora, cada vez mais bem informadas e educadas, tornaram-se parte importante dos conflitos internacionais, passando a demandar também a capacidade de influenciar o curso dos acontecimentos que, afinal, diriam respeito a suas próprias vidas. Guardadas as proporções, fenômeno semelhante observou-se no campo do comércio e das finanças internacionais e na definição de políticas tendentes a promover a inserção das economias no mercado internacional ${ }^{18}$.

Se o século XIX viveu o debate sobre o melhor regime cambial a ser adotado, finalmente vencido, incrementalmente, pela instalação de um regime internacional baseado no padrão-ouro, no século XX teve lugar a falência desse sistema de intermediação de trocas e a necessária abertura de espaço em que pudessem operar agentes políticos quando da adoção de regimes cambiais específicos. Para não mencionar as flutuações observadas ao longo dos vinte anos de crise que marcaram o entreguerras, durante os quais os governos claramente cederam a interesses específicos de curto prazo que se entrechocavam em suas sociedades, o padrão ouro-dólar, adotado depois da Segunda Guerra Mundial, estabeleceu um sistema predominantemente liberal e relativamente previsível, marcado pela peculiaridade de as- 
O Sistema Político dos EUA: Implicações para suas Políticas Externa e de Defesa

segurar, sempre, a possibilidade de acomodação, pelos governos, de interesses políticos específicos ${ }^{19}$.

Obviamente, a participação mais intensa das sociedades nos processos decisórios dos governos não ocorreu - e não ocorre - de forma linear e serena; tampouco resulta de concessões dos governos em resposta a pacíficas reivindicações de suas populações. Demandas inerentes aos primeiros estágios da intensificação das relações econômicas internacionais ensejaram, de início, intervenções dos Estados nos mercados, seguidas de maior liberalização resultante da percepção, por parte destes mesmos Estados, de que seus interesses estariam mais bem atendidos pelo aproveitamento de vantagens comparativas. Surtos de crescimento levaram a uma integração de mercados que, se bem impulsionada por processos tecnológicos típicos da Revolução Industrial (tais como o telégrafo, a máquina a vapor e os navios frigoríficos) e pela estabilidade dos valores relativos dos ativos financeiros proporcionada pelo padrão-ouro, só mostrou sua intensidade durante a crise de 1929.

Em meio à crise, as populações recorreram aos Estados, na esperança de que eles pudessem restabelecer condições capazes de proteger os interesses coletivos. É certo que os movimentos nazifascista e comunista, na Europa, constituíram marcantes exemplos de centralização do poder, engendrando riscos às liberdades individuais, como ensinou Hayek (1994) no Caminho da Servidão; mas nos EUA o governo, inspirado em idéias keynesianas, também implementou políticas tendentes a reduzir liberdades individuais. As políticas articuladas pelo New Deal e as tarifas comerciais dos anos 1930 ilustram a consolidação de poder no âmbito do governo federal, cujo início costuma ser localizado pelos historiadores na promulgação da Constituição, em 1787.

Entre os pontos de inflexão que caracterizaram o fortalecimento da União, em detrimento dos estados e das cidades, destacam-se a Guer- 
ra de Secessão e a era Roosevelt, cujas políticas, posteriormente aprofundadas, em certos aspectos, por Johnson, passaram a requerer uma redivisão da arrecadação tributária, em favor da União, destinada a sustentar os programas federais.

Não obstante a concentração de poder nos Estados Nacionais, em detrimento dos governos locais, observada em várias partes do mundo desde o fim da Primeira Guerra Mundial, a relação entre governantes e governados transformou-se em favor destes. Em parte, esse fenômeno contribuiu para que, organizada, a sociedade se valesse de novas condições de acesso a outros governos para perseguir seus interesses.

Outra dimensão desse processo foi motivada pelo estabelecimento de interesses privados que se organizaram através das fronteiras nacionais, envolvendo parcelas crescentes das populações e das empresas aptas a garantir a arrecadação dos governos dos Estados Nacionais. Nessas codições, tais governos tenderam a produzir regras comuns tanto para a organização de mercados unificados quanto para o combate a ameaças comuns. Entre as implicações dessa tendência, esteve a alienação de parte da autonomia decisória dos governos em benefício não apenas da criação de melhores condições de desenvolvimento para suas economias, mas também da ampliação das possibilidades de responder, com eficácia, a ameaças oriundas de crimes transnacionais.

Em conseqüência, nunca antes se observou, na esfera internacional, tamanha fragmentação e complexidade nas relações de poder entre agentes políticos os mais diversos, que, ao interagir, engendram processos políticos que, contínua e dinamicamente, redefinem relações de poder e de autoridade em várias áreas da vida internacional. Essa fragmentação de poder decorre, em parte, das condições atuais do contexto internacional, em que agentes privados (não necessariamente interessados em lucro) lutam por suas demandas e requerem, 
O Sistema Político dos EUA: Implicações para suas Políticas Externa e de Defesa

de modo articulado, regras claras para disciplinar suas mútuas interações $^{20}$.

De outra parte, argumenta-se que a fragmentação de processos políticos e a existência de múltiplos canais de acesso a núcleos de poder na arena internacional resultam da influência de normas e valores norte-americanos embutidos nas estruturas de regulação da ordem mundial. De alguma maneira, o papel central desempenhado pelos EUA ao longo do século XX terá contribuído para a consolidação de um ambiente regulatório marcado por instituições que permitem numerosas possibilidades de acesso a centros de poder, ora participando de instituições e de encontros sobre temas específicos, como se observou na "década das conferências", ora interferindo na agenda política internacional.

Nesse sentido, o ambiente internacional teria funcionado - e continuaria a funcionar - como um veículo da influência dos EUA, já que nele se inserem os sistemas políticos de diversos Estados Nacionais. O cerne do argumento pode ser resumido da seguinte forma: os sistemas nacionais necessariamente se relacionam com o ambiente externo, que, obviamente, constitui um sistema fechado; uma vez que nele prevalecem características da sociedade norte-americana, as trocas efetuadas entre os numerosos sistemas domésticos e o contexto internacional terminam por promover maior homogeneização das relações internacionais, diluindo idiossincrasias de cada comunidade política - exceto as dos EUA, que se fazem presentes também na ordem internacional.

No que concerne à economia política internacional, entre as melhores análises da influência dos EUA sobre as estruturas internacionais está a de Strange (1989). De acordo com sua proposta de análise, o poder estrutural sobrepõe-se, como instrumento de influência sobre o comportamento de outros agentes, às tradicionais formas de pressão, usualmente constituídas de estímulos positivos (promessas de 
benefícios) e negativos (ameaças), a que Olson deu o nome de incentivos seletivos. Para Strange (idem:168), "poder estrutural aproxima-se da definição ampla (isto é, abrangente) de 'regimes' no debate que precedeu a coletânea de ensaios organizada por Krasner sobre o tema. Em síntese, ela abrange costumes, usos e modos de operacionalização, em contraste com a definição mais restritiva que se refere a acordos entre Estados e a instituições centradas nos Estados".

Nesse contexto, ainda segundo Strange, a hegemonia norte-americana revela-se no domínio de suas empresas sobre a economia global, na prevalência de suas técnicas administrativas, contábeis e de marketing $^{21}$, na ampla difusão da cultura norte-americana pelo cinema, televisão e mídia, na enorme atração que seu sistema universitário exerce sobre os melhores cérebros do mundo, enfim, na difusão, mundo afora, de práticas típicas da sociedade norte-americana.

Poder-se-ia acrescentar a esta enumeração a utilização das regras das bolsas de valores norte-americanas como fundamento para as transações internacionais e a absorção, por organizações internacionais, de normas cuja justificativa moral se fundamenta na cultura liberal, mais bem enraizada e desenvolvida nos EUA do que em qualquer outra parte do mundo. Afinal, como se sabe, a semelhança entre o preâmbulo da Carta da Organização das Nações Unidas (We the peoples...) e a Declaração de Independência norte-americana não se deve a uma coincidência. Em suma, para autores como Strange (idem: 170$)^{22}$, a presença norte-americana no mundo constitui nova forma de império, um império que já não requer definição territorial, visto que a autoridade "é exercida diretamente sobre o povo, não sobre o território. Ela é exercida sobre banqueiros e executivos de empresas, sobre investidores e poupadores em geral, sobre jornalistas e professores. Ela é também, obviamente, exercida sobre as mentes de funcionários dos governos aliados e associados, como ilustram as sucessivas conferências de chefes de Estado". 
O Sistema Político dos EUA: Implicações para suas Políticas Externa e de Defesa

Os anos de exercício do poder estrutural, especialmente do poder brando, e de institucionalização de uma ordem internacional relativamente pluralista permitiram ampliar a presença dos EUA em praticamente todas as partes do mundo, o que, a um tempo favoreceu a aceleração do desenvolvimento tecnológico e dele colheu frutos, especialmente no que concerne à infra-estrutura de transportes e comunicações. Esse processo não reduziu, contudo, a capacidade do governo e da sociedade norte-americana de acumular recursos de poder (econômicos, culturais, tecnológicos, políticos e militares) suficientes para tornar sua liderança inquestionável no futuro previsível. Autores como Haas (2005) não apenas reconhecem o fenômeno, mas defendem a necessidade de os EUA aproveitarem essas condições para concretizar, de forma permanente, sua liderança sobre uma sociedade marcada por instituições tendentes a preservar valores de liberdade e democracia.

$\mathrm{O}$ fato de as estruturas sobre as quais se fundamentam os canais que servem para veicular as trocas internacionais não serem neutras, mas favorecerem a sociedade norte-americana (e/ou agentes nela formados), contribui para que se observe crescente concentração de recursos nos EUA. As evidências estão no número dos registros de patentes, no generoso financiamento de déficits comerciais e públicos dos EUA, na crescente participação de empresas norte-americanas em áreas de fronteira tecnológica, na capacidade que sua sociedade possui de polarizar, ora positiva, ora negativamente, as ações de governos e de grupos organizados em todas as regiões do mundo.

Esse processo, contudo, também encerra custos para a sociedade norte-americana. Por exemplo, os fluxos migratórios prevalecentes nos últimos anos vêm desequilibrando as proporções tradicionais de grupos étnicos e culturais na sociedade norte-americana, gerando tensões apenas parcialmente absorvidas pelo sistema político, como ilustrou o debate entre os candidatos às eleições majoritárias com a população de origem hispânica ${ }^{23}$. Além disso, observou-se o desen- 
volvimento de um novo tipo de imigrante, mais preocupado em ganhar dinheiro e retornar a sua terra de origem do que em realizar "o sonho americano". Não obstante essas tensões, fortemente acentuadas pelos acontecimentos de 11 de Setembro e, principalmente, pela reação do governo norte-americano, a projeção de interesses dos EUA no mundo vem se tornando não apenas mais profunda, mas também mais complexa. Trata-se, com efeito, de uma espécie de influência, um tipo de liderança que se constrói, de um lado, por meio de estruturas materiais, institucionais e normativas, capazes de estabelecer regras para as interações internacionais que, embora negociadas e aceitas por todos, em larga medida privilegiam agentes já habituados a atuar na sociedade norte-americana ${ }^{24}$.

Assim, não tem lugar propriamente uma imposição de interesses de um governo a outros, mas o estabelecimento de estruturas de governança que, a exemplo de quaisquer outras, beneficiam alguns agentes em detrimento de outros, particularmente no que se refere a custos de transação $^{25}$. Uma vez que se recoloca o problema em termos da relação entre agentes e estruturas, nesse caso uma estrutura regulatória das relações comerciais, não se observa propriamente algo concreto contra o que possam lutar os que se sentem prejudicados no atual contexto internacional. As condições que interessam ao governo e à sociedade norte-americana são definidas na forma de idéias (algumas embutidas em instituições de que a maioria dos governos é signatária, portanto responsável), alcançando um grau de intangibilidade que lhes assegura melhores possibilidades de perpetuarem-se.

A anarquia própria ao sistema internacional contribui para que as relações de poder e de autoridade entre agentes internacionais se redefinam continuamente, inclusive por meio do permanente questionamento das "regras do jogo" e de sua transformação. Assim como na sociedade norte-americana, no ambiente internacional prevalece um sistema político pluralista, relativamente aberto à participação de diferentes agentes dispostos a avançar seus interesses mediante efetiva 
O Sistema Político dos EUA: Implicações para suas Políticas Externa e de Defesa

participação na formulação de normas, na definição de agendas, no estabelecimento de instâncias recursais para as quais possam ser transferidos determinados temas sobre os quais não se consegue produzir consenso.

Em resumo, na sociedade norte-americana e na esfera internacional prevalecem instituições e normas que embutem formas de solução de conflitos fortemente associadas à cultura norte-americana; formas inclusive testadas ao longo da história dos EUA. Ao universalizarem um conjunto de idéias a respeito do modo como os agentes devem se comportar no plano político e das regras que devem servir a organizar um ambiente em progressiva integração, ao conferirem a agentes políticos dispersos geograficamente oportunidades de acesso a processos decisórios internacionais, a sociedade e o governo norte-americanos exercem liderança sutil, mas não menos eficaz sobre processos sociais, políticos e econômicos no âmbito internacional.

Neste ambiente, idéias e valores tidos como universais (tais como o conceito de direitos humanos definidos em função dos indivíduos e a representação política por meio de partidos políticos em sistemas eleitorais) ${ }^{26}$ estruturam os processos políticos internacionais de modo a valorizar a capacidade de atuação de agentes isolados, os quais se relacionam com os Estados Nacionais por meio de cálculos de custos e benefícios em um ambiente marcado por regras que lhes permitem continuamente redefinir lealdades políticas em função de interesses específicos, passíveis de serem contabilizados.

Em certo sentido, a "grande transformação" de que tratou Polanyi (1944) estende-se às relações internacionais: as instituições norte-americanas (desenhadas para proteger os indivíduos da tirania dos governos), que mais profundamente sedimentaram valores mercantis como instrumentos de intermediação de relações sociais, gradualmente conformam as normas internacionais. Ao fazê-lo, definem-lhes os valores principais e abrem espaço à evolução de proces- 
sos políticos que, contínua e dinamicamente, facultam a cada agente a possibilidade de alterar sua capacidade de interferir nos principais processos internacionais ${ }^{27}$. Vejamos, então, de forma mais detida, a origem e as características dos valores principais na sociedade norte-americana.

\section{Valores no sistema político norte-americano e sua projeção na esfera internacional}

Nesta parte do texto, serão discutidos valores específicos da sociedade e do sistema político norte-americano. Ao longo dos anos, esses valores influenciaram fortemente a definição de interesses que, de forma permanente, fundamentaram a política externa dos EUA praticamente desde o século XIX. Além da prevalência da idéia de destino manifesto e da pragmática identificação de interesses nas relações com outras nações, sobretudo no plano comercial, será discutida a idéia de fronteira em permanente expansão e, nesse contexto, a maior importância relativa dos indivíduos em seu relacionamento com o governo. Ao longo do texto, pretende-se aludir, ainda, à importância que tiveram esses valores para a construção da ordem internacional contemporânea.

\section{O destino manifesto}

A instituição do sistema político norte-americano deu-se com base em ampla reflexão dos Pais Fundadores, cujas discussões públicas, em dia com a mais avançada produção no campo da filosofia política da época, registraram preocupações com definir a identidade nacional e com estabelecer normas que perpetuassem os valores em nome dos quais se declarou a independência. Desde então, além dos documentos legais, um conjunto de textos, entre os quais se destacam os Artigos 
O Sistema Político dos EUA: Implicações para suas Políticas Externa e de Defesa

Federalistas e discursos de presidentes como Washington, Jefferson e Lincoln, influencia as decisões políticas nos Estados Unidos.

O famoso discurso de despedida de Washington ${ }^{28}$, por exemplo, revela clara consciência dos interesses de longo prazo dos EUA e da necessidade de bem conduzir suas relações desde o primeiro momento. No que diz respeito aos objetivos a serem perseguidos na esfera internacional, Washington sustentou a idéia de que deveria prevalecer como regra o isolacionismo, temperado por bem escolhidas intervenções alhures, sempre que houvesse avaliação positiva de custos e benefícios. Principalmente, Washington sugeria a seus sucessores que caberia evitar que se manifestassem, no seio da sociedade norte-americana, preferências por países específicos, tais como as facções que, favoráveis à França e à Grã-Bretanha (e em conflito umas com as outras), em seu governo colocaram em risco a frágil União, tão duramente construída. Assim, segundo Washignton, para que, fundada na religião e na moralidade, a "grande nação americana" pudesse realizar o seu destino manitesto, isto é, "oferecer à humanidade o magnífico e novíssimo exemplo de um povo sempre guiado pelo sentido de justiça e benevolência [...] [N]ada é mais essencial do que evitar inveteradas antipatias permanentes contra nações particulares, bem como de apegos apaixonados a outras; e, em seu lugar, devem ser cultivados apenas sentimentos de amizade para com todas" (Washington, 1996).

A política externa dos EUA deveria guiar-se, pois, pelos interesses nacionais, "observando boa fé e justiça para com todas as nações" (idem) e definindo suas relações com base em análises racionais dos interesses do país, visto que políticas influenciadas por sentimentos facilmente criariam "a ilusão de [...] interesses comuns imaginários, onde não existem interesses reais" (idem). Estava claro que "a grande regra de conduta para nós com relação a nações estrangeiras consiste em estender nossas relações comerciais, de modo a ter com elas a menor conexão política possível" (idem). Envolver-se com a Europa, 
então, tenderia a trazer apenas prejuízos aos reais interesses norte-americanos: "Por que, ao entrelaçar nosso destino com o de qualquer parte da Europa, comprometer nossa paz e prosperidade com processos políticos europeus marcados por ambição, rivalidade, interesses, humores ou caprichos?" (idem)

Embora alianças, desde que temporárias, pudessem ser necessárias para proteger os interesses nacionais em circunstâncias específicas, cabia tirar proveito de "nossa situação desapegada e distante [...] para escolher paz ou guerra, tal como o nosso interesse, guiado pelo senso de justiça, deve aconselhar" (idem). Em síntese, tratava-se de "ganhar tempo para o nosso país estabelecer e tornar maduras suas jovens instituições, e progredir sem interrupções até o grau de força e consistência que é necessário para dar-lhe [...]. O comando de sua própria fortuna" (idem).

O texto de Washington é emblemático porque explicita, de um lado, a intenção de projetar valores e interesses no sistema internacional, um claro sentido de missão guiado por fortes convicções sobre o certo e o errado, sobre ações e imagens positivas e negativas na esfera internacional. O discurso de George W. Bush em West Point, em junho de 2002, cujos excertos permeiam a Estratégia de Segurança Nacional em vigor, nada tem de novo, portanto. Sua linguagem explicitamente fundada em convicções sobre o "certo e o errado" apenas reafirma, com palavras, a disposição para continuar a agir em favor do cumprimento do destino manifesto da nação:

"A causa por que luta a nossa nação sempre foi mais ampla do que a sua defesa. Hoje, como sempre, nós lutamos por uma paz justa - uma paz que favoreça a liberdade. Nós defenderemos a paz contra as ameaças de terroristas e tiranos. Nós preservaremos a paz ao construir boas relações com as grandes potências. E nós estenderemos a paz ao encorajar sociedades livres e abertas em cada continente" ${ }^{\prime 29}$ (Bush, 2002).

É curiosa a semelhança entre a retórica norte-americana, que recoloca, em nome do interesse nacional e do destino manifesto, a necessi- 


\section{O Sistema Político dos EUA: Implicações para}

suas Políticas Externa e de Defesa

dade de universalizar a democracia e as liberdades individuais, e a posição dos países europeus que se opuseram à intervenção norte-americana no Iraque. Afinal, por um lado, esses países basearam sua oposição no argumento de que a ação militar tenderia a produzir desastre humanitário e fragilizaria as instituições internacionais por meio das quais se vinha levando a cabo o mesmo processo de universalização de valores democráticos mundo afora. Por outro lado, os EUA não apenas foram o país que mais procurou fortalecer essas instituições nas décadas subseqüentes à Segunda Guerra, mas também tentaram justificar sua ação em nome de resoluções anteriores do Conselho de Segurança, fazendo uso de discursos fortemente marcados pela defesa da ordem multilateral ${ }^{30}$.

Ao cabo, fica claro que ambas as propostas visam induzir a transformação de costumes e instituições (tradicionais em numerosos países) incompatíveis com valores democráticos e liberais. Ironicamente, políticas de difusão de valores democráticos e liberais são vistas, elas próprias, como incompatíveis com conceitos de democracia, o que alimenta, em países de cultura islâmica, resistências a esses valores e oposições aos EUA.

Nessas condições, observam-se tensões entre vários governos europeus e o governo norte-americano (e seus aliados). Freqüentemente atribuídas ao maior grau de unilateralismo associado à atual administração norte-americana, essas tensões têm elevado os custos de negociações em processos políticos complexos e relevantes, sobretudo quando se negocia a necessária cooperação em assuntos relativos à não-proliferação de armas de destruição em massa e às diversas dimensões de combate ao terrorismo, entre as quais a lavagem de dinheiro. Claramente, percebe-se a necessidade de a atual liderança norte-americana buscar reaproximar-se de líderes de outras grandes potências: se parece ter sido fácil encontrar em Washington inspiração para discurso normativo, pode ser mais difícil buscar nele o sentido de racionalidade necessário a evitar que as ações externas se dei- 
xem guiar por simpatias e antipatias, por convicções sobre interesses externos que eventualmente são percebidos como norte-americanos e que, em última instância, aparentemente têm servido apenas para produzir a oposição entre facções no seio da própria sociedade norte-americana.

As intervenções eventuais em outras partes do mundo foram mais freqüentes no século XX, em contraste com o relativo isolacionismo que marcou os EUA durante o século XIX, quando prevalecia a opinião de que era preciso consolidar a União e produzir prosperidade. Como se sabe, isso implicou, entre outras decisões da sociedade norte-americana, a renúncia ao modelo de produção baseado nas grandes propriedades, na produção agrícola extensiva e na escravidão, conforme brilhantemente analisado por Marx em artigos publicados na época da Guerra de Secessão. Afinal, mais importante do que os argumentos morais em defesa da condição humana dos negros norte-americanos ${ }^{31}$, foi o fundamento econômico da guerra: subjacente ao confronto entre o Sul e o Norte, intensificava-se o conflito entre métodos de produção econômica contraditórios e o risco de que os diferentes entendimentos sobre a melhor maneira de organizar a economia e a sociedade norte-americana levassem à secessão de uma União duramente promovida, como deixou entender Lincoln já em seu discurso de posse. De um lado, a escravidão; de outro, a consciência de que era preciso assegurar a permanente expansão do mercado interno, dada a necessidade de crescimento da massa salarial sem a qual a industrialização não poderia prosseguir, sem a qual a promessa de prosperidade não se realizaria.

O resultado da Guerra de Secessão levou à redefinição da posição dos EUA no mundo. Uma redefinição que, na verdade, consolidou o contraponto à posição relativamente isolacionista propugnada por Washington. Como bem observa Gaddis (2004) em seu mais recente livro, a resposta de John Quincy Adams ao ataque britânico à capital norte-americana que incendiou a Casa Branca, no início do século 
O Sistema Político dos EUA: Implicações para suas Políticas Externa e de Defesa

XIX, baseou-se em uma estratégia marcada pelo unilateralismo, pela busca da hegemonia no plano regional e pela possibilidade de "ataques preventivos". A própria expansão territorial foi fortemente influenciada pela percepção de Adams de que cabia evitar que algo semelhante ao que hoje se denominam "Estados falidos" utilizassem territórios próximos às fronteiras norte-americanas para abrigar possíveis inimigos dos EUA, selvagens ou civilizados. Por essa razão, Adams pressionou a Espanha, durante o período em que ela controlou a Flórida, para que policiasse com eficácia seu território ou cedesse ao governo norte-americano a província, já que isso lhe parecia necessário para assegurar os interesses nacionais norte-americanos.

O mesmo tipo de argumento seria utilizado, anos depois, por Theodore Roosevelt, William Taft e Woodrow Wilson em suas justificativas para intervenções na Venezuela, na República Dominicana, no Haiti, na Nicarágua e no México. Na mesma linha, seguiram os sucessivos governos norte-americanos ao longo da Guerra Fria, ora em terras distantes, com a frágil "teoria do dominó" como argumento para sustentar que era preciso conter o comunismo, ora no continente, por meio tanto de ações multilaterais no âmbito da Organização dos Estados Americanos (OEA) quanto de iniciativas que, velada ou abertamente, implicavam imiscuir-se em assuntos políticos internos aos países situados em sua "área de influência".

Em todos esses casos, o unilateralismo e a antecipação em relação a eventos cuja evolução apenas se podia presumir marcaram a política externa norte-americana. Em todos eles, prevaleceu, na política externa do país, a determinação de manter a preponderância em todas as dimensões de poder - tão criticada na atual estratégia de segurança nacional dos EUA -, em especial a militar. Em vez de apostar no funcionamento do equilíbrio de poder, tratou o governo norte-americano de combinar, ao longo da história, o isolacionismo, temperado por pragmáticas relações comerciais com todas as nações, e a projeção de valores e instituições globais em conjunto com amplas inter- 
venções em momentos críticos. Além das alianças de guerra durante os conflitos mundiais, a manifestação de uma supremacia inconteste, incorporada, nos dias que correm, na retórica que expõe a Doutrina Powell e em ações tais como as duas guerras do Golfo.

Assim, além da decisiva participação nas duas guerras mundiais, sucessivos governos dos EUA promoveram políticas externas mais agressivas, ora concentrando-se no hemisfério ocidental (Monroe, ainda no século XIX, e praticamente todos os governos do pós-Segunda Guerra, com variações na intensidade das intervenções), ora atuando em outras regiões do mundo. De sua parte, o governo norteamericano, republicano ou democrata, não se preocupa agora, e não se preocupava no passado, em negar ou omitir esse interesse, definindo como objetivos principais:

“[...] a sobrevivência dos Estados Unidos como uma nação livre e indepedente, com seus valores fundamentais intactos e suas instituições e povo seguros. [...] Os Estados Unidos buscam, sempre que possível de forma concertada com seus aliados:

- deter qualquer agressão que possa ameaçar a segurança dos Estados Unidos e seus aliados e - no caso de falhar a distensão - repelir ou derrotar ataques militares e resolver conflitos em termos favoráveis para os Estados Unidos, seus interesses e seus aliados;

- contra-arrestar efetivamente ameaças à segurança dos Estados Unidos, seus cidadãos e seus interesses, incluindo a ameaça do terrorismo internacional" (The White House, 1991).

Anos depois, documento análogo afirma:

"Este é um mundo em que distinções claras entre ameaças à segurança de nossa nação oriundas do exterior de nossas fronteiras e desafios à nossa segurança originados dentro de nossos limites estão sendo misturados; em que a separação entre problemas internacionais e domésticos está se evaporando; e em que a linha entre política interna e política externa está se erodindo. [...] Nós não somos a polícia do mundo, mas, na condição de maior potência econômica e militar, e com a força de nossos valores democráticos, o engajamento dos EUA é indispensável para forjar relações políticas está- 


\section{O Sistema Político dos EUA: Implicações para suas Políticas Externa e de Defesa}

veis, para tornar o comércio mais livre e para avançar nossos interesses. [...] Nossa liderança deve enfatizar a diplomacia preventiva - por meios tais como o apoio à democracia, a assistência econômica, a presença militar no ultramar, a interação entre militares norte-americanos e estrangeiros, e o envolvimento em negociações multilaterais no Oriente Médio e em outras partes do mundo - com vistas a contribuir para resolver problemas, reduzir tensões e esvaziar conflitos antes que eles se tornem crises. Essas medidas constituem um sábio investimento em nossa segurança nacional porque elas oferecem a perspectiva de resolver problemas com o menor custo humano e material possível" (The White House, 1996).

Essa posição encontra, claro, sólidos precedentes. Em parte inspirado em Mahan, em parte fundamentando suas ações em idéias próprias, Theodore Roosevelt, procurou transformar os EUA em agente decisivo na esfera internacional. De início, expandiu o poder naval norte-americano, engendrando o processo que transformou o país, em poucos anos, na maior potência naval do planeta, como se demonstrou na Primeira Guerra Mundial. Em seguida, perseguiu a política de "Portas Abertas" na Ásia, especialmente na China. Em pouco tempo, firmou importantes interesses econômicos e comerciais na região. Ademais, mediou as negociações que puseram fim à guerra entre Rússia e Japão, cujas implicações se manisfestaram tanto na Revoução de 1917 quanto na redefinição do equilíbrio de poder na época, mediante a ascensão do Japão à condição de grande potência. Por fim, o famoso "Corolário Roosevelt" complementou, em termos conceituais, a Doutrina Monroe, indicando a percepção do governo norte-americano com relação a suas intenções no hemisfério e servindo de inspiração ao que, na Guerra Fria, veio a ser definido como "esferas de influência". Em outras palavras, como observam Wittkopf e McCormick (2004) na introdução à excelente coletânea de artigos sobre as fontes domésticas da política externa norte-americana, fatores culturais e institucionais contribuem, desde os primórdios da formação do país, para definir as linhas gerais de implementação da política norte-americana. A seguir, um desses fatores será discutido de modo mais profundo. 


\section{Fronteiras em expansão}

As mudanças tecnológicas que transformaram o século XX, produzidas e desenvolvidas sobretudo - não por acaso - no dinâmico ambiente constituído pela sociedade e pela economia norte-americana, contribuíram para que se revisassem a natureza e o significado das relações de poder na esfera internacional. Em larga medida, esse processo foi responsável pelo resultado da Guerra Fria: a vitória dos EUA sobre a União Soviética no período que Gaddis chamou de "longa paz" foi causada tanto pela dimensão econômica e política quanto pela militar. Por seu turno, em grande medida, características da sociedade norte-americana, entre as quais cabe destacar a idéia de fronteira em permanente expansão, contribuíram para que se desenvolvesse esse processo.

Nesse período, a Guerra do Vietnã constituiu evidência de que a definição de interesses dos EUA no mundo e a condução de ações destinadas a concretizar esses interesses haviam se tornado processos bastante complexos. De um lado, a noção de segurança nacional já não se construía com base exclusivamente na idéia de se garantir proteção ao território (fato que se agravou com o advento dos mísseis intercontinentais), abrindo espaço para que se identificassem interesses nacionais em todas as partes do globo. De outro lado, mesmo distante geograficamente, pelas ondas do rádio e da televisão, a guerra fez-se presente nos lares norte-americanos, ensejando novo fortalecimento da população em sua relação com o governo, até no que dizia respeito a temas de política externa.

A opinião pública norte-americana, que afinal levou seu governo a capitular diante da resistência vietnamita, viu-se ainda mais fortalecida em sua capacidade de influenciar as decisões políticas depois da renúncia do presidente Richard Nixon. Em alguma medida, a idéia de uma fronteira em expansão, agora uma fronteira tecnológica, serviu de pano de fundo para essas mudanças. Como resultado, já que 
O Sistema Político dos EUA: Implicações para suas Políticas Externa e de Defesa

sempre se pode estender a fronteira, ganha força a percepção de um processo que funciona como uma espécie de jogo de soma variável e positiva, visto que, mesmo assimetricamente, todos poderão beneficiar-se dos frutos da expansão tecnológica.

A crescente consciência de que o conhecimento aplicado à produção explica a forte expansão econômica e, pelo menos teoricamente, de que a capacidade de produzir bem-estar encontra seus limites na (infinita?) criatividade humana, presente na obra de Locke (1952) e finalmente demonstrada por Solow (2000), encontrou solo fértil na sociedade norte-americana. Com efeito, nela reuniram-se tradições que explicam, em parte, seu dinâmico crescimento: sólidas instituições políticas, prolongada estabilidade econômica, razoáveis condições de segurança e fortes expectativas de cumprimento de contratos uniram-se como fatores que, articulados, muito contribuíram para favorecer inovações e investimentos de longo prazo. Baumol (2002) explica esse fenômeno de forma brilhante e sucinta.

Ademais, o espírito empreendedor típico da ética protestante, auxiliado pela mentalidade de imigrante, facilitou a assunção de risco pelos agentes privados. Por sua vez, a permanente preocupação com melhorias de infra-estrutura básica no país permitiu a mobilidade dos cidadãos e a perfeita integração de mercados (entre os quais o mercado de trabalho), cujos dinamismo e inovação foram auxiliados por níveis de proteção tarifária historicamente baixos. Por fim, a competitividade e o fascínio exercido pelo ambiente acadêmico atraíram - e, a despeito das duras regras de imigração estabelecidas no pós-11 de Setembro, continua a atrair - muitos dos melhores cérebros do mundo para os EUA, permitindo que lá se produza conhecimento de ponta.

Nessas condições, a fronteira que interessa se transforma substantivamente, migra para outras dimensões da realidade, mas permanece em expansão. Não surpreende, portanto, que a crença na eficácia, efetividade e eficiência dos mecanismos de mercado como forma de 
solucionar conflitos se tenha firmado, ela própria, entre os valores da sociedade norte-americana.

No atual contexto internacional, as novas condições tecnológicas favorecem a integração, em redes, de partes do território norte-americano às regiões mais dinâmicas do globo. O desafio, mundo afora, já não consiste em conquistar territórios e subjugar povos; menos ainda em recolher espólios de guerra ou extorquir antigos adversários. Trata-se, pelo contrário, de celebrar contratos em função de normas aceitas por todos e percebidas como universais; normas construídas, contudo, sobre valores mercantis.

Assim, consolida-se uma estrutura normativa de alcance global, a que voluntariamente aderem governos e outros agentes na esfera internacional, quase todos sem ao menos questionar os valores embutidos nas normas desenhadas para uma sociedade atomizada, em que apenas a expectativa de cumprimento dos contratos fornece perspectiva de autocontenção do uso da força, que passa a funcionar como principal instrumento de regulação eficaz dos níveis de violência.

Gradualmente, na esfera internacional, impõem-se estruturas normativas cuja autoridade reside, a um tempo, no simples fato de serem normas e na sua justificação fundamentada na adesão voluntária de indivíduos soberanos. De um lado, o simples fato de expressar um comando universal, que prescreve ou proscreve um padrão de comportamento, confere à lei uma posição de autoridade. A autoridade da lei amplia-se à proporção que, por meio de um processo de mistificação, os indivíduos que a ela se submetem presumem que esse comando tenha resultado de uma prévia relação de autoridade entre agentes políticos. O tema não é novo: Montaigne observou que o cumprimento da norma não se deve à presunção de sua justiça:

“[...] as leis conservam seu prestígio não por serem justas, mas porque são leis. Esse é o fundamento místico de sua autoridade; não têm outro. [...] Isso lhes é muito proveitoso. Freqüentemente são feitas por tolos, mais freqüen- 


\section{O Sistema Político dos EUA: Implicações para suas Políticas Externa e de Defesa}

temente por pessoas que devido à aversão pela igualdade têm falta de eqüidade, porém sempre por homens - autores vãos e incertos" (Montaigne, 2001, livro III, cap. XIII:434).

De outro lado, permanece o pacta sunt sevanda, a necessidade de se organizarem as relações entre agentes livres e auto-interessados, cujas interações são difíceis e complexas, donde a necessidade de que os contratos se firmem na dupla presunção, quase sempre implícita, de que se está falando a verdade e de que os acordos serão honrados. A própria definição moral do que é certo passa a ser informada, assim, pelo cumprimento do compromisso voluntariamente estabelecido por indivíduos livres ${ }^{32}$.

Nesse contexto, ganham relevo conceitos como o de "bem comum", elaborado pela teoria da ação racional para explicitar o modo como cada integrante do grupo assente, mediante cálculos de custo e benefício, arcar com sua parcela de responsabilidade para que se atinja o interesse coletivo. Obviamente, o "comportamento carona" é sempre uma possibilidade, razão pela qual cabe estabelecer estruturas de incentivos seletivos adequadas a constranger cada integrante do grupo a alinhar seus interesses individuais aos da coletividade (Olson, 1965; 1982; 2000). Não constitui coincidência, portanto, o fato de esse mecanismo de produção de ações coletivas ser mais estudado, conhecido e aplicado nos EUA do que em qualquer outra sociedade. Pouco a pouco, contudo, sua prática se torna universal. O amálgama das relações sociais passa a definir-se, gradualmente, em função de interesses individuais registrados em contratos, explícitos ou tácitos, capazes de fazer convergir as expectativas de agentes nas diversas áreas das relações internacionais ${ }^{33}$.

Se é verdade que a construção de uma ordem internacional fundada em valores liberais constitui processo lento e contínuo (Ruggie, 1982), não seria falso afirmar que houve pontos de inflexão nesse processo. Por exemplo, Pfaff (1993) argumenta que a nova ordem internacional proposta por George Bush logo após o final da Guerra 
Fria se caracterizou por um reformismo institucionalista que "presume que uma assembléia de governos constitui, ao menos potencialmente, uma forma de democracia mundial" (idem:205). Mas, já que “[...] a vasta maioria dos membros das Nações Unidas é formada, na verdade, por governos não-representativos, oligarquias vinculadas a classes ou a interesses específicos, ditaduras ou, ainda, déspotas no sentido primeiro da palavra, [...] ela se parece muito pouco com uma agência capaz de estabelecer a democracia mundial e o respeito internacional pelos direitos humanos" (ibidem).

Ao considerar a Organização das Nações Unidas inapta a promover a democratização das decisões internacionais, dado seu baixo grau de legitimidade democrática, Pfaff parece não se dar conta de que a própria idéia de democratização por meio da representação de interesses e posições políticas em instituições assemelhadas a assembléias constitui a extensão de um valor atlântico a outras culturas, nas quais distintas formas de representação de interesses - não raro fundadas em mitos de criação e em vinculações divinas - foram mais freqüentes ao longo da história. A criação racional de instituições políticas adequadas a mediar conflitos sociais sofreu influência mais forte da experiência norte-americana do que de qualquer outra fonte. $\mathrm{Na}$ mesma linha, sua dinâmica capacidade de adaptação também se vem transferindo às instituições internacionais. Com efeito, como observa Scheffer (1989:1),

“[...] a exemplo da Constituição dos Estados Unidos, a Carta [das Nações Unidas] é um documento em permanente expansão que deve responder a um mundo em rápidas mudanças, em que o arranjo de segurança coletiva do imediato pós-Segunda Guerra Mundial entrou em colapso. Do ponto de vista da escola dos aliados, as palavras genéricas da Carta devem ser lidas pragmaticamente à luz das circunstâncias em transformação em um mundo turbulento. Isso implica revisar o Direito Internacional de modo a torná-lo compatível com os objetivos de política externa dos Estados Unidos e de seus aliados".

Em outras palavras, de um lado, tem-se a forte presença dos EUA em todos os processos decisórios relevantes no âmbito internacional - 
O Sistema Político dos EUA: Implicações para suas Políticas Externa e de Defesa

muitos dos quais têm lugar em instituições e por meio de regras constituídas no pós-Segunda Guerra Mundial, sob os auspícios do Estado norte-americano ${ }^{34}$. De outro lado, a difusão de práticas, valores e instituições norte-americanas, que passou também a intermediar as interações de agentes políticos internacionais.

Uma vez que se ressalta a natureza universal das normas e a adesão voluntária aos regimes internacionais - mas não seu inevitável viés axiológico -, não se percebe a ordem internacional contemporânea propriamente como uma imposição, sobretudo porque a relação principal já não envolve apenas diferentes agentes, uns em permanente conflito e cooperação com os outros; a relação que fundamentalmente define as estruturas de incentivos aos agentes - por conseguinte, também suas agendas - tem lugar entre estruturas e agentes. Ocorre que, ao se submeterem coletivamente às estruturas vigentes, os agentes engendram processos que distribuem custos e benefícios de forma assimétrica.

Não se trata, portanto, de uma "ordem justa", por não serem justas suas normas; não se trata de uma ordem simples, pois não se identifica claramente o modo como se exerce a dominação, como se influenciam as percepções e o comportamento de agentes específicos. Afinal, a influência se exerce por meio de idéias e valores, pela retórica defesa da liberdade individual (ora referindo-se a Estados Nacionais, ora a seres humanos, conforme o nível de análise em que se construam os discursos) e pela promesssa de uma felicidade geral resultante da soma das felicidades dos indivíduos atomizados - e não de laços de solidariedade construídos em função de valores estranhos a cálculos de custo e benefício.

Não por acaso, a revolta diante do abismo entre expectativas e possibilidades nessa ordem predominantemente liberal, que efetivamente produz riqueza e desigualdade, volta-se também para os símbolos mais caros àqueles que são percebidos como os principais beneficiá- 
rios da "nova ordem mundial". Nessas condições, bandeiras norte-americanas incendiadas em toda parte e ataques aos símbolos do poder econômico e militar no 11 de Setembro; como resultado, pânico de novos ataques a cada data nacional e a perplexidade da classe média norte-americana, que não consegue compreender a razão pela qual, no mundo inteiro, retribui-se sua genuína solidariedade missionária, agora concretizada também em obras de fundações e empresas, com sentimentos crescentemente hostis aos EUA (Nye, 2004). Consequientemente, ainda, observa-se a silenciosa satisfação com que, em toda parte, há quem observe as dificuldades enfrentadas pelos EUA no Iraque e em casa, em matéria de direitos civis, e o crescente chamado ao governo para fortalecer o multilateralismo indispensável à solução duradoura de seus principais problemas, nenhum dos quais se origina exclusivamente de fatores domésticos.

Afinal, em parte graças às peculiaridades do sistema político norte-americano, a intensa relação com os EUA produziu mudanças em várias partes do mundo. Chettle (1995), por exemplo, argumenta que, ao longo dos anos, a dinâmica evolução do sistema político norte-americano

“[...] criou uma seqüência alternada de comportamentos do tipo 'bom policial - mau policial' que criou dificuldades não apenas para o relacionamento entre os EUA e seus oponentes, mas também se revelou profundamente desestabilizadora para regimes ditatoriais. [...] [Assim,] porque não podia dar respostas de uma sociedade livre e poderosa, a única alternativa à disposição dos déspotas consistia em isolar seu país de um contato com os Estados Unidos ou tê-lo encapsulado pelos próprios Estados Unidos - em outras palavras, transformar-se em algo como Cuba ou Coréia do Norte" (idem:4-6).

Para o autor, as distintas orientações de política externa em relação a países como África do Sul e União Soviética, resultantes da alternância entre democratas e republicanos na Casa Branca e das mudanças de percepção da opinião pública sobre temas específicos, contribuí- 
O Sistema Político dos EUA: Implicações para suas Políticas Externa e de Defesa

ram para desestruturar as reações que os governos desses países ensaiavam esboçar às políticas norte-americanas.

Nessas condições, "a dialética da política externa norte-americana" (ibidem), fortemente influenciada pela defesa mais ou menos intensa da idéia de liberdade individual, "é uma força muito poderosa, uma tensão criativa que o sistema político norte-americano efetivamente produz" (ibidem). Ao longo do tempo, em relação à África do Sul, a alternância entre um engajamento construtivo e a imposição de sanções contribuiu para fortalecer, no plano interno, os opositores dos governos autoritários, além de haver tornado pública a execração de práticas racistas, especialmente a partir dos anos 1970. Em sua relação com a ex-União Soviética, por seu turno, o governo dos EUA alternou propostas de coexistência pacífica e fortes aumentos no orçamento militar acompanhados de ameaças e de ambiciosos projetos de dissuasão. Por fim, "a estratégia dos Estados Unidos, como um resultado inconsciente de sua própria complexa natureza, ajudou a produzir a desintegração desses dois sistemas de governo hostis, tornando possível uma mudança pacífica" (idem:18).

A instigante análise de Chettle não deixa de conferir maior relevância ao comportamento do Estado, nesse caso considerado eficaz no que diz respeito à produção de resultados inesperados. Essa inconstância no comportamento do governo decorre, em parte, do pluralismo de seu sistema político, preparado para preservar as fundamentais liberdades de opinião, de associação e de acesso a processos decisórios relevantes. Sua projeção no exterior ocorre por meio da idéia de fronteira, que continua norteando a atuação política do governo dos EUA, além de ser um valor subjacente na formação da sociedade norte-americana; em suma, um fator de identidade nacional.

Com efeito, o norte-americano-padrão tem sempre como valor a possibilidade de expandir sua condição de vida, daí os EUA serem identificados por antropólogos - e pelo senso comum - como uma terra 
de oportunidades. A natureza da fronteira, contudo, transformou-se. Já não se trata de um território a ocupar - embora em algumas circunstâncias isso possa ser considerado algo necessário.

A idéia de fronteira concretiza-se hoje, de um lado, na conquista de mercados, o que requer a homogeneização de normas e a aceitação, em diferentes jurisdições, dessas normas; de outro lado, a fronteira é também tecnológica, e seu limite permanece em expansão: enquanto houver imaginação, é possível produzir novos conhecimentos, desenvolver novas tecnologias, transformar a natureza em benefício do homem, como defendeu Locke (1952) no Segundo Tratado, texto que influenciou fortemente as discussões dos Pais Fundadores. Para tanto, é preciso não só assegurar as liberdades individuais e o direito de propriedade como também criar condições para que os melhores cérebros possam radicar-se nos EUA ou, pelo menos, trabalhar em função de interesses que sejam convergentes com os norte-americanos.

Nos Estados Unidos, a expansão da fronteira deu-se, de início, pela conquista do Oeste. À necessidade de ouro para atender à demanda por liquidez gerada pela revolução industrial, somaram-se as sucessivas ondas de imigração e a percepção do governo de que a exploração da fronteira era um bom modo de promover a ocupação de seu território e sua eventual ampliação. Na prática, o papel da fronteira serviu, historicamente, como uma espécie de válvula de escape para pressões políticas sobre o governo, pois os indivíduos tendem a assumir a responsabilidade pelo fracasso na obtenção de condições econômicas mais satisfatórias. Na raiz de todo o processo, permanece a profunda aceitação de valores igualitários, que enfatizam a autonomia dos indivíduos (Wood, 1991).

\section{Conclusão}

A interdependência observada nas relações internacionais contemporâneas caracteriza-se pela existência de vasos comunicantes entre 
agentes políticos internos e externos. Esses agentes, entre os quais se encontram os governos dos Estados Nacionais e os órgãos de suas burocracias, avançam seus interesses em ambientes regulados por normas cujos efeitos não se restringem a esferas isoladas, seja a interna, seja a internacional. A definição das regras dos diferentes jogos em que se envolvem os agentes políticos - ela própria um processo político - requer dos agentes, no mínimo, a capacidade de compreender essa interpenetração de normas e valores; e, no máximo, a capacidade de atuar em diferentes arenas, de modo a, por exempo, buscar por meio de processos tipicamente característicos de política externa atingir objetivos tradicionalmente concebidos como sendo de política doméstica ${ }^{35}$.

A depender do grau de abertura dos sistemas políticos a pressões e interesses específicos, agentes estrangeiros podem inserir em processos decisórios domésticos suas demandas, que, se vierem a ser aceitas pelos governos em vigor, passam a ser consideradas legítimas na jurisdição em que pretendiam inserir-se ou até mesmo contempladas pelos orçamentos de que tencionavam participar.

Os EUA definiram, no pós-Segunda Guerra Mundial, estruturas regulatórias (algumas delas apoiadas por organizações internacionais) que embutem valores liberais, embora reservem espaço a eventuais ações dos governos, destinadas a conter pressões políticas internas. Ao longo desse período, observou-se a utilização da política externa como instrumento de promoção de valores partidários, assim como de valores consensuais da sociedade norte-americana, o que contribuiu para que, do exterior, se percebesse o governo dos EUA como possuidor de vontades inconstantes.

Em contrapartida, verificou-se também a crescente presença de temas externos na política norte-americana, os quais ganham relevo em épocas eleitorais. Inevitavelmente, os partidos políticos buscam fortalecer sua identidade, veicular valores com os quais se identifi- 
cam, visando, internamente, aumentar a coesão de seus quadros e, em sua relação com a sociedade, conquistar votos.

Constata-se, nesse contexto, mudança na intensidade das influências que fatores externos podem exercer sobre processos políticos tipicamente domésticos, mesmo nos EUA. É óbvio que tais influências têm lugar permanentemente, por meio de grupos de pressão, da organização de comitês de eleitores, da participação em debates capazes de influenciar a opinião pública, dos próprios incentivos embutidos nas normas que disciplinam processos políticos mundo afora. Constata-se também, ato contínuo, a elevação da influência que dinâmicas internas, especialmente em países como os EUA, exercem sobre processos políticos internacionais.

Como se argumentou aqui, valores, práticas e instituições tipicamente norte-americanas podem ser identificadas nas normas e instituições internacionais, como resultado não apenas do relevante papel desempenhado pelo país nas últimas décadas, mas também de sua política externa, empenhada tanto em alcançar seus interesses específicos quanto em contribuir para realizar o destino manifesto da nação. As contradições inerentes ao sistema político dos EUA e a ênfase na construção de um arcabouço institucional que protegesse os indivíduos, de par com a importância conferida à idéia de fronteira em permanente expansão, contribuíram para fortalecer agentes privados mundo afora, a um tempo tornando os processos políticos internacionais mais parecidos com os norte-americanos e trazendo temas outrora estranhos à sociedade norte-americana para o debate interno.

O resultado do processo foi sintetizado pelo escritor Gore Vidal (apud Strange, 1989:1): “O império norte-americano é uma das invenções mais bem-sucedidas da História; e é ainda mais notável porque ninguém se dá conta de que ele está por toda parte". 


\section{O Sistema Político dos EUA: Implicações para suas Políticas Externa e de Defesa \\ Notas}

1. A citação indica a essência da estratégia estabelecida por Lawrence para combater alemães e turcos, fortemente superiores, na península árabe (Lawrence, 1991:192).

2. Cabe lembrar que este processo se aprofundou a partir de fins dos anos 1970 e início dos anos 1980, quando a chamada "revolução liberal" de Thatcher e Reagan restabeleceu as condições de produtividade na economia mundial ao radicalizar instituições liberais nesses países, contribuindo para fortalecer o papel da democracia como forma de organização política e o liberalismo como norte da organização de esforços produtivos mundo afora. Ao cabo, o processo contribuiu não apenas para encerrar a Guerra Fria, mas também para acelerar o ritmo do processo de interdependência em âmbito global. A melhor análise do processo continua sendo a de Fukuyama (1992).

3. Embora o debate seja antigo (Hoffmann, 1959; Carr, 1964) e estivesse em curso, mantinha-se restrito a estudiosos do Direito Internacional e de áreas específicas da análise das relações internacionais. Boa síntese e instigante argumento aparecem, por exemplo, em Kratochwill (1989).

4. Estruturas materiais e intangíveis; estruturas políticas, econômicas e sociais; estruturas de idéias, de normas e valores mais ou menos compartilhados por indivíduos dispersos geograficamente, com múlltiplas lealdades políticas. Ver Wendt (1987) e Onuf (1998).

5. A primeira proposta de tratamento sistemático do tema surgiu a partir da discussão de Singer (1961) a respeito de níveis de análise.

6. Ver, por exemplo, Strange (1988). De outro ponto de vista, Milner (1997).

7. Ver Nye (1990; 2002). Essa preocupação tampouco é nova: Carr (1964) destacou a necessidade de se considerar o "poder sobre as idéias" como importante instrumento de pressão na política internacional.

8. A discussão encontra-se em Rosow et alii (1994) e Rosenau (1997). Por outro prisma, Keohane (1984a; 1984b).

9. Evidências empíricas deste processo abundam: dos números do comércio internacional (não obstante a redução de fluxos observada entre fins da Primeira Guerra Mundial e o fato de Bretton Woods só ter funcionado plenamente nos anos 1960) à mundialização das estruturas produtivas; da homogeneização de padrões de consumo à circulação de informações em tempo real; da unificação do sistema financeiro internacional à efetiva integração de redes de tráfico de 


\section{Antonio Jorge Ramalho da Rocha}

drogas, armas e seres humanos... Em toda parte se constata o aprofundamento da interdependência das sociedades e Estados e o crescimento da demanda pela definição de regras globais para um mundo progressivamente integrado. Uma implicação desse processo sobre a qual pouco se reflete é a demanda no sentido de se redefinir o próprio conceito de segurança, mediante, por exemplo, a associação da idéia de segurança à permanência de estruturas regulatórias (segurança jurídica) ou à provisão de condições mínimas de bem-estar das populações (segurança humana).

10. Não por acaso, os documentos que resumem a estratégia de segurança nacional dos EUA mencionam a necessidade de se promover a integração de mercados e a consolidação de democracias mundo afora, como forma de avançar os interesses norte-americanos e de reafirmar sua liderança. Para mencionar apenas os principais textos, ver National Security Strategy (1991; 1996; 2002), disponíveis em <http://www.whitehouse.gov/>.

11. A respeito de redes, ver Castells (1996).

12. O primeiro autor a formular a hipótese impiíssima, então tida como absurda por indicar a prescindibilidade de Deus na formação de um Direito das gentes, foi Grotius (2001), em De Jure Belli ac Pacis.

13. Neste exemplo, como em outros casos de Direito Internacional Privado, a adoção de um ou outro padrão pelas nascentes soberanias foi fortemente condicionada pelo grau de influência que sobre seus sistemas jurídicos exercia o Direito Romano tradicional.

14. Documento disponível em <http://www.archives.gov/national-archivesexperience/charters/declaration.html $>$.

15. Via-se a experiência norte-americana não apenas como a primeira tentativa de se implementar, em uma situação real, as idéias republicanas de um governo submetido aos cidadãos; nela, viam-se condições favoráveis a que se enraizassem nesse novo Estado instituições liberais: terra rica, proteção dos oceanos e indivíduos dispostos a arriscar-se, já que, em sua maioria, fugiam de guerras religiosas e opressões políticas.

16. Ver Constituição dos Estados Unidos da América, disponível em $<$ http://www.archives.gov/national-archives-experience/charters/constitution.html>.

17. O sentido de missão civilizadora (que ecoa tanto as motivações religiosas dos primeiros colonizadores quanto as noções racistas de "ônus do homem branco", já observadas no início da fase mercantilista da colonização) marcaria a atuação externa dos EUA a partir de então, quer via políticas governamentais, 


\section{O Sistema Político dos EUA: Implicações para suas Políticas Externa e de Defesa}

quer por meio de iniciativas genuinamente sociais, entre as quais se destacaram - e se destacam - missões religiosas e obras assistenciais e educacionais de empresas e fundações. Esse aspecto da inserção internacional dos EUA, de que voltarei a tratar mais adiante, é bem resumido, por exemplo, por Ferreira (2000).

18. Boa síntese da evolução do sistema financeiro internacional encontra-se em Eichengreen (1996).

19. A respeito do Sistema de Bretton Woods e sua característica de prevalência do liberalismo temperada por espaços para a absorção de pressões políticas específicas, ver Ruggie (1982).

20. Em sua instigante análise, Rosenau (1990; 1997) caracterizou o atual contexto internacional como uma espécie de bifurcação de processos oriundos de "dois mundos": em um deles, prevaleceriam as tradicionais relações internacionais, marcadamente influenciadas por agentes "dotados de soberania"; no outro, agentes destituídos de soberania, mas nem por isso menos capazes de estabelecer relações de autoridade com outros, seriam os principais responsáveis por iniciar processos e, dessa maneira, condicionar a agenda internacional.

21. A própria ausência de tradução para outros idiomas do conceito em inglês pode ser vista como evidência dessa dominação.

22. Suas idéias foram inspiradoras, mas podem ser mais bem desenvolvidas com o auxílio de argumentos teóricos como os de Nye, Onuf e Wendt, posteriores a suas intuições.

23. Para não mencionar a mais recente polêmica inaugurada por Huntington (2004).

24. Dois exemplos saltam aos olhos, um no setor privado, outro envolvendo Estados Nacionais. De um lado, a necessária adoção, por empresas transnacionais de todas as origens, de padrões contábeis definidos em função do sistema norte-americano implica vultosos custos operacionais; sem isso, contudo, seus balanços não são levados em conta por investidores e sua condição passa a ser considerada pouco transparente, fazendo com que suas ações não sejam negociadas em bolsas; por conseguinte, sua presença em mercados globais torna-se inviável. No que concerne aos Estados, a definição das regras do comércio internacional e os mecanismos de solução de controvérsias na Organização Mundial do Comércio (OMC), claramente inspirados no Common Law, funcionam como uma espécie de extensão, aos países-membros da OMC, de processos e arcabouço regulatório tipicamente característicos do sistema político norte-americano, inclusive no que diz respeito à possibilidade de se veicularem propostas de novas regras e interpretações por meio de ações de lobby. 


\section{Antonio Jorge Ramalho da Rocha}

25. Isso não significa que essas estruturas não contribuam para reduzir custos de transação e assimetrias de informação, como demonstra o argumento neoliberal institucionalista - ver, por exemplo, Keohane (1984a; 1984b) e Keohane e Nye (2003). Entretanto, os custos de adequação a essas estruturas são diferenciados conforme os agentes, sendo que, na ordem internacional contemporânea, os privilegiados são os que já trabalham sob os padrões vigentes na sociedade norte-americana.

26. Valores que, segundo Tocqueville (1977:540), permitiram aos habitantes da América instituir uma "sociedade nova", em que "os bens e os males se repartem com razoável igualdade no mundo".

27. Para outro prisma de análise, ver Grossi (2004).

28. Disponível em <http://www.yale.edu/lawweb/avalon/washing.htm>.

29. Embora a linguagem faça referência a "grandes potências", em contraste com a visão mais universalista de Washington (o que em parte retrata as diferenças entre a posição dos EUA daquela época e de agora), o crucial é a consciente projeção de valores nas relações com outras culturas, sempre fundada na convicção - não necessariamente correta - de que, ao fazê-lo, os EUA têm a seu lado a justiça e a moralidade.

30. Curiosamente, embora o governo dos EUA tenha sido acusado de, por meio da operação militar no Iraque, haver deslegitimado a Organização das Nações Unidas, desde o primeiro momento ele não apenas justificou sua ação com base na necessidade de fazer cumprir resoluções anteriores do mesmo Conselho de Segurança, como também planejou o ingresso de missão de paz imediatamente depois das operações militares mais intensas. A incisiva postura diplomática dos neoconservadores que assessoram o presidente Bush, contudo, foi percebida por analistas e governantes como atitude arrogante, descompromissada com as instituições internacionais e mesmo com valores outrora caros aos próprios norte-americanos. Contribuiu, assim, para opor parte da opinião pública internacional - notadamente na Europa - e muitos governos à decisão de intervir no Iraque, assim como para desgastar a imagem dos EUA na esfera internacional.

31. Na verdade, um problema apenas parcialmente resolvido a partir dos anos 1960, com os movimentos pelos direitos civis, inspirados pelo sonho de Martin Luther King, com as decisões da Suprema Corte e com o início de políticas de ação afirmativa.

32. Ver Onuf (1989). Filosoficamente, o substrato da ordem enraiza-se, é claro, em Locke. 


\section{O Sistema Político dos EUA: Implicações para suas Políticas Externa e de Defesa}

33. Não surpreende, portanto, o surgimento de extensa literatura sobre regimes internacionais, a começar pelo já clássico texto de Krasner (1983).

34. Para não mencionar o deliberado uso de seu "poder brando", pela veiculação de mídia e pela oferta de bolsas de estudo, para proporcionar às elites do mundo inteiro uma formação informada sobre e, na medida do possível, simpática à cultura norte-americana. Sobre o declínio dessa capacidade, ver Nye (1990; 2002; 2004).

35. A esse respeito, ver Putnam (1988) e Milner (1997).

\section{Referências Bibliográficas}

BAUMOL, William. (2002), The Free Market Innovation Machine. Princeton, Princeton University Press.

BUSH, G. W. (2002), "President Bush Delivers Graduation Speech at West Point”. Disponível em <http://www.whitehouse.gov/news/releases/2002/ 06/20020601-3.html>.

CARR, Edward H. (1964), The Twenty Years' Crisis, 1919-1939. New York, Harper \& Row Pubs.

CASTELLS, Manuel. (1996), The Rise of the Network Society. Oxford, Blackwell Publishers.

CHETTLE, Jeffrey. (1995), “The American Way: Or How the Chaos, Unpredictability, Contradictions, Complexity, and Example of Our System Undid Communism and Apartheid”. The National Interest, pp. 3-18.

EICHENGREEN, Barry. (1996), Globalizing Capital. New York, Cambridge University Press.

FERREIRA, Oliveiros. (2000), “Segurança, Comércio e Ideologia”, in S. P. Guimarães (org.), Estados Unidos - Visões Brasileiras. Brasília, IPRI/FUNAG.

FUKUYAMA, Francis. (1992), The End of History and the Last Man. London, Hamish Hamilton. 


\section{Antonio Jorge Ramalho da Rocha}

GADDIS, John L. (2004), Surprise, Security and the American Experience. New York, Oxford University Press.

GROSSI, Paulo. (2004), Mitologias Jurídicas da Modernidade. Florianópolis, Fundação Boiteux.

GROTIUS, H. (2001), On the Law of War and Peace. Kitchener, Batoche Books.

HAAS, Richard. (2005), The Opportunity - America's Moment to Alter History's Course. New York, Public Affairs.

HAYEK, F. A. (1994), The Road to Serfdom. Chicago, University of Chicago Press.

HOBBES, T. (1996), Leviathan. Oxford, Oxford University Press.

HOFFMANN, Stanley. (1959), "International Relations: The Long Road to Theory". World Politics, vol. XI, nº 3 .

HUNTINGTON, Samuel. (1996), The Clash of Civilizations and the Remaking of World Order. New York, Simon and Schuster.

(2004), "Who Are We? The Challenges to America's National Identity". Foreign Policy Magazine, no 141, pp. 1-14.

KEOHANE, Robert. (1984a), “The Demand for International Regimes”. International Organization, vol. 36, nº 2, pp. 325-355.

(1984b), After Hegemony. Cooperation and Discord in the World Political Economy. Princeton, Princeton University Press.

e NYE, J. (2003), Power and Interdependence. Princeton, Princeton University Press.

KRASNER, Stephen. (1983), International Regimes. Ithaca, Cornell University Press.

KRATOCHWILL, F. (1989), Rules, Norms, and Decisions. On the Conditions of Practical and Legal Reasoning in International Relations and Domestic Affairs. Cambridge, Cambridge University Press.

LAWRENCE, Thomas E. (1991), Seven Pillars of Wisdom - A Triumph. New York, Anchor Books. 


\section{O Sistema Político dos EUA: Implicações para suas Políticas Externa e de Defesa}

LOCKE, J. (1952), The Second Treatise of Government. New York, Prentice-Hall.

MAQUIAVEL, N. (1985), Discourses. London, Viking.

MILNER, Helen. (1997), Interests, Institutions, and Information. Domestic Politics and International Relations. Princeton, Princeton University Press.

MONTAIGNE, Michel. (2001), Ensaios. São Paulo, Martins Fontes.

NYE, Joseph S. (1990), Bound to Lead - The Changing Nature of American Power. New York, Basic Books.

. (2002), O Paradoxo do Poder Americano. São Paulo, UnESP.

. (2004), The Decline of American Soft Power". Foreign Affairs, vol. 83, no 3 .

OLSON, Mancur. (1965), The Logic of Collective Action. Cambridge, Harvard University Press.

Press.

(1982), The Rise and Decline of Nations. Cambridge, Harvard University

. (2000), Power and Prosperity. Outgrowing Communist and Capitalist Dictatorships. New York, Basic Books.

ONUF, Nicholas. (1988), World of Our Making. Rules and Rule in Social Theory and International Relations. Columbia, University of South Carolina Press.

. (1989), World of Our Making. Rules and Rule in Social Theory and International Relations. Columbia, University of South Carolina Press.

. (1998), The Republican Legacy in International Thought. Cambridge, Cambridge University Press.

PFAFF, William. (1993), The Wrath of Nations - Civilization and the Furies of Nationalism. New York, Touchstone.

POLANYI, K. (1944), The Great Transformation. New York, Farrar and Rinehart.

PUTNAM, R. (1988), "Diplomacy and Domestic Politics. The Logic of Two Level Games”. International Organization, vol. 42, nº 4, pp. 427-460. 


\section{Antonio Jorge Ramalho da Rocha}

ROSENAU, James. (1990), Turbulence in World Politics. A Theory of Change and Continuity. Princeton, Princeton University Press.

. (1997), Along the Domestic-Foreign Frontier - Exploring Governance in a Turbulent World. Cambridge, Cambridge University Press.

ROSOW, Stephen, INAYATULLAH, Naeem e RUPERT, Mark. (1994), The Global Economy as a Political Space. Boulder \& London, Lynne Rienner Publishers.

ROUSSEAU, J.-J. (1968), The Social Contract. London, Penguin Classics.

RUGGIE, John G. (1982), “International Regimes, Transactions, and Change: Embedded Liberalism in the Postwar Economic Order". International Organization, vol. 36, nº 2, pp. 379-415.

SCHEFFER, David. (1989), "Introduction: The Great Debate of the 1980's”, in L. Henkin, S. Hoffmann, J. J. Kirkpatrick, A. Gerson e W. D. Rogers (eds.), Right vs Might: International Law and the Use of Force. New York, Council of Foreign Relations Press.

SINGER, J. David. (1961), "The Level of Analysis Problem in International Relations", in K. Knorr e S. Verba (eds.), The International System:Theoretical Essays. Princeton, Princeton University Press, pp. 77-92.

SOLOW, R. (2000), Growth Theory - An Exposition (2 ${ }^{\mathrm{a}}$ ed.) Oxford, Oxford University Press.

STRANGE, Susan. (1988), States and Markets: An Introduction to International Political Economy. London, Basil Backwell.

(1989), "Toward a Theory of Transnational Empire", in J. Rosenau e E-O Czempiel, Global Changes and Theoretical Challenges: Approaches to World Politics in the 1990's. Lexington, Lexington Books.

TESCHKE, Benno. (2002), "Theorizing the Westphalian System of States: International Relations from Absolutism to Capitalism". European Journal of International Relations, vol. 8, nำ pp. 5-48.

THE WHITE HOUSE. (1991), "National Security Strategy of the United States". Disponível em <http://www.fas.org/man/docs/918015-nss.htm)>. 
O Sistema Político dos EUA: Implicações para suas Políticas Externa e de Defesa

. (1996), "A National Security Strategy of Engagement and Enlargement". Disponível em <http://www.fas.org/spp/military/docops/national/1996stra.htm>.

TOCQUEVILLE, Alexis. (1977), Democracia na América. Belo Horizonte, Ed. Itatiaia.

WASHINGTON, George. (1996), "The Avalon Project: Washington's Farewell Address 1796". Disponível em <http://www.yale.edu/lawweb/avalon/washing.htm>.

WENDT, Alexander. (1987), "The Agent-Structure Problem in International Relations Theory”. International Organization, vol. 41, n 3, pp. 335-370.

. (1999), Social Theory of International Politics. Cambridge, Cambridge University Press.

WITTKOPF, Eugene e McCORMICK, James. (2004), The Domestic Sources of American Foreign Policy - Insights and Evidence. New York, Rowman \& Littlefield Pub. Inc.

WOOD, Gordon. (1991), The Radicalism of the American Revolution. New York, Vintage Books. 


\section{Resumo}

\section{O Sistema Político dos EUA: Implicações para suas Políticas Externa e de Defesa}

$\mathrm{O}$ artigo discute a condição e o grau de interdependência prevalecente no atual contexto internacional e analisa, por diferentes perspectivas teóricas, suas origens e evolução recente. Ao argumentar que os EUA exercem forte influência na redefinição das "regras do jogo" no plano internacional, examina as bases institucionais e culturais em que se fundamenta a política externa norte-americana. Por fim, avalia a extensão em que os EUA utilizam normas e valores como instrumentos de projeção de sua influência no ambiente internacional contemporâneo.

Palavras-chave: Estados Unidos - Política Externa Norte-americana Interdependência - Normas Internacionais - Regimes Internacionais

\section{Abstract}

\section{Influences of the American Political System on US Foreign and Defense Policies}

This article examines, from different theoretical perspectives, the characteristics and the degree of interdependence that prevail in current international relations. It argues that the US plays a key role in redefining the "rules of the game" in the international realm, while examining the cultural and institutional basis on which American foreign policy is rooted. Finally, it evaluates the extent in which the US government uses norms and values as instruments to project its influence in current international relations.

Key words: United States - American Foreign Policy - Interdependence - International Law - International Regimes 